\title{
FAULT-HOSTED PALYGORSKITE FROM THE SERRATA DE NÍJAR DEFORMATION ZONE (SE SPAIN)
}

\author{
E. García-Romero ${ }^{1}{ }^{*}$, M. Suárez ${ }^{2}$, R. Oyarzun ${ }^{1}$, J. A. López-García ${ }^{1}$ and M. Regueiro ${ }^{1,3}$ \\ ${ }^{1}$ Departamento de Cristalografia y Mineralogia, Facultad de Ciencias Geológicas, Universidad Complutense, Madrid, Spain \\ ${ }^{2}$ Departamento de Geologia, Universidad de Salamanca, Plaza de la Merced s/n, 37008 Salamanca, Spain \\ ${ }^{3}$ Instituto Geológico y Minero de España, Ríos Rosas, 23, 28003 Madrid, Spain
}

\begin{abstract}
Palygorslite fibers growing along fault planes in the outcrops of a large fault zone in SE Spain (Carboneras Fault Zone: CFZ; Serrata de Nijar) were studied by X-ray diffraction, scanning electron microscopy-energy dispersive $\mathrm{X}$-ray analysis, and transmission electron microscopy-analytical electron microscopy. The structural formulae, calculated per half unit-cell, is: $\mathrm{Si}_{7.95} \mathrm{Al}_{0.05} \mathrm{O}_{20}\left(\mathrm{Al}_{1.93} \mathrm{Fe}_{0.08} \mathrm{Mg}_{1.92}\right)$ $(\mathrm{OH})_{2}\left(\mathrm{OH}_{2}\right)_{4} \mathrm{Na}_{0.09} \mathrm{~K}_{0.01} \mathrm{Ca}_{0.03} 4\left(\mathrm{H}_{2} \mathrm{O}\right)$. The samples have minor tetrahedral substitutions, with $\mathrm{Mg} / \mathrm{Al}$ ratios close to one, and contain very small amounts of $\mathrm{Fe}^{3+}$. The number of octahedral cations per half unitcell is 3.93. The fault-hosted palygorskite shows macroscopic ductile features including incipient foliation. Based on field and laboratory observations, as well as on regional geological evidence indicating the existence of widespread hydrothermal processes along the Serrata de Nijar and surrounding areas, we suggest that palygorshite may have formed during ongoing deformation in the CFZ, as a precipitate from Mg-rich hydrothermal fluids.
\end{abstract}

Key Words-Fault Gouge, Fault Zone, Macroscopic Palygorskite, Serrata de Nijar, Smectite, Spain.

\section{INTRODUCTION}

The brittle field of deformation in fault zones has been studied extensively from the viewpoint of the mechanical behavior of minerals. However, little has been said in terms of the chemical processes that lead to mineral formation. For example, it is well known that large brittle shear zones develop intense colors (e.g. red, yellow, green, purple), which are related to significant changes in the mineralogy of the rocks, that are crushed and transformed into fault gouge (e.g. Sibson, 1990; Vrolik and van der Pluijm, 1999). Clay minerals account for large proportions of the mineral assemblages developed in fault gouges. These minerals have classically been studied from the viewpoint of low $T$-low $P$ chemical processes under exogenous conditions (e.g. soil formation). However, the study of hydrothermal mineral deposits, particularly porphyry copper, precious metal epithermal deposits, and geothermal fields during the 1960 s and 1970s offered some clues to the role of the hydrothermal solutions that alter volcanic or plutonic complexes (Hemley and Jones, 1964; Hemley et al., 1969; Montoya and Hemley, 1975, among others). Most porphyry copper and epithermal deposits and geothermal fields share one feature in common: they all present argillic or advanced argillic alteration mineral assemblages, including the formation of montmorillonite and/ or kaolinite (among others) (e.g. Heald et al., 1987;
Eaton and Setterfield, 1993, among others). For example, kaolinite forms in the low-pH environment that triggers the so-called advanced argillic alteration. On the other hand, minerals of the smectite group form under milder $\mathrm{pH}$ conditions. All this brings us to the case of palygorskite (attapulgite), a mineral classically related to exogenous processes, although also present in the hydrothermal environment of $\mathbf{M g}$-rich solutions altering Mg-rich magmatic rocks (basalts, dunites), which has been found associated with fault gouges or hydrothermal veins (Bowles et al., 1971; Haji-Vassiliou and Puffer, 1975; Furbish and Sando, 1976; Gibbs et al., 1993, among others). However, no discussion on the causeeffect relationships between structural setting, deformation, hydrothermal fluid circulation, and mineral deposition has been provided. Moreover, even though clays are a common component of fault gouge, their genesis and importance in this location are still poorly understood (Vrolik and van der Pluijm, 1999). Those authors also recognized the fact that the interplay between clay mineral formation and mechanical deformation within fault zones should be regarded as a single integrated process, and that clay gouges actively evolve during faulting. We report here a case of palygorskite formation within secondary faults in a large fault zone in SE Spain (Figure 1), and provide some clues to help understand mineral deposition within this environment.

\section{MATERIALS AND METHODS}

* E-mail address of corresponding author: mromero@geo.ucm.es
The samples were collected in the Serrata de Nijar (Figure 1) near the road that connects the towns of Nijar and San José. We selected a highly deformed and 

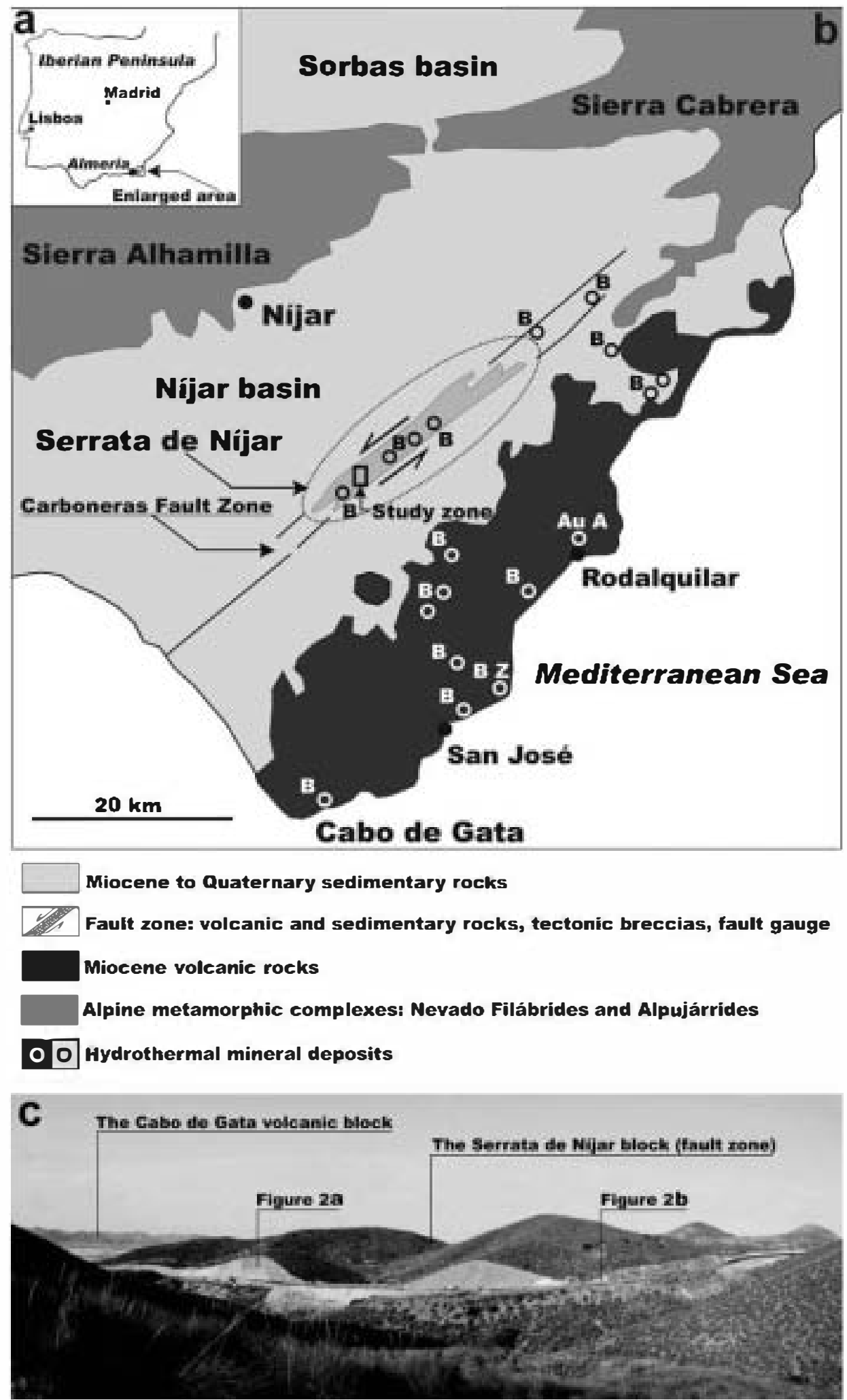

Figure 1. (a) Location of the study zone within the Iberian peninsula. (b) Simplified scheme depicting the major geological units of the region. (c) A partial view (looking south) of the Serrata de Nijar and the Cabo de Gata block. Hydrothermal mineral deposits after Reyes et al. (1987), Oyarzun et al. (1995), and this work; A: alunik; Au: gold; B: bentonike, Z: zeolite. 

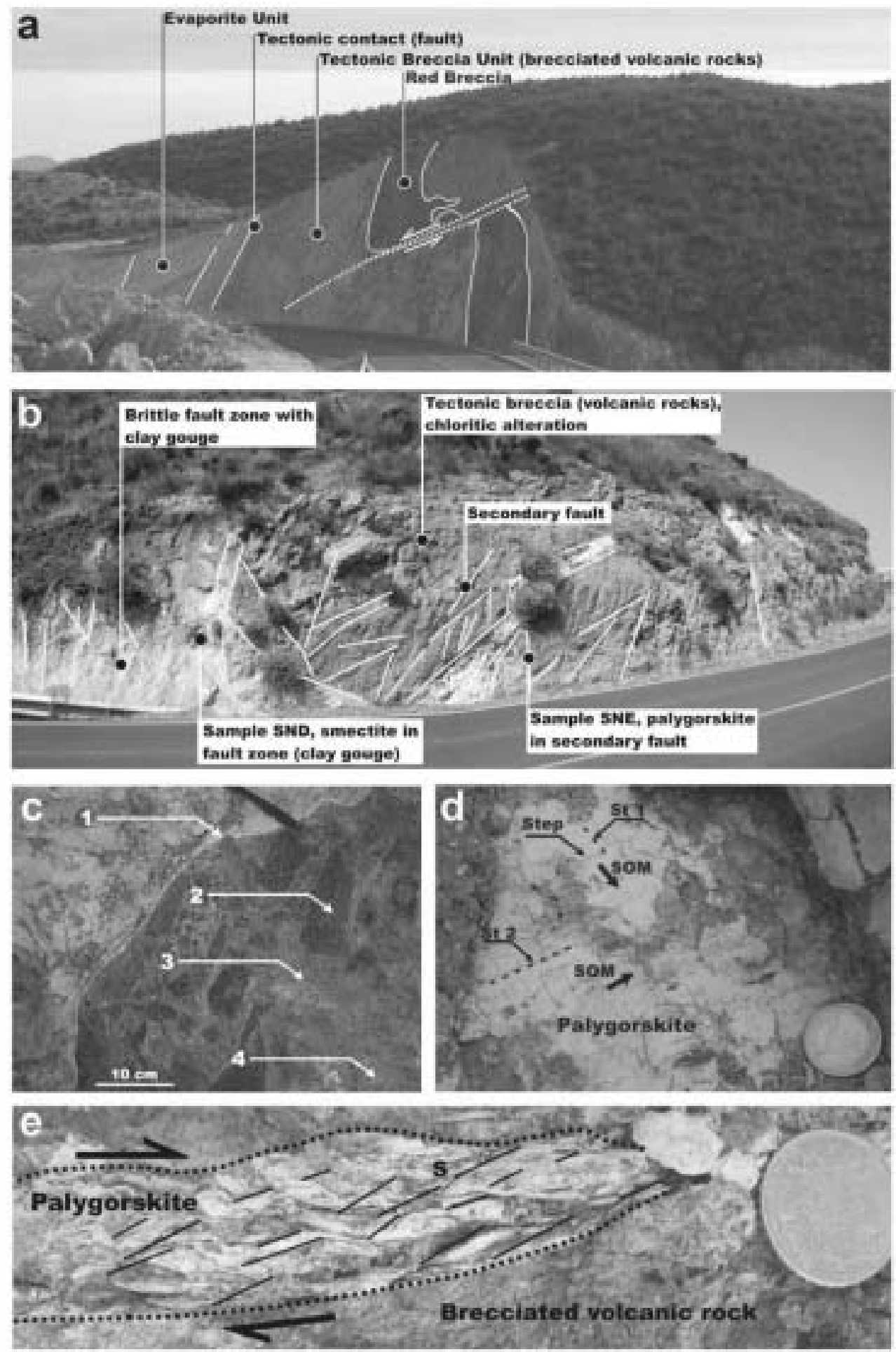

Figure 2. (a) Faulting, deformation anddispositionof rock units along a segmentof the Serrata de Nijar. Nove the highly deformed Red Breccia unit, and see also Figure 1c for location within a larger conkext. (b) Dispositionof structural units, faulting and location of samples. Solidlines: faults. See also Figure $1 \mathrm{c}$ for location withina larger context. (c) Large breccia clast of previously brecciated andesike: (1) Rod Breccia clast; (2) andesike clast floating within a fine fluidized matrix; (3) goethike-clay rich matrix; (4) andesike clasts per vasively alkered to chlorik. (d) Kinematic indicators (striations: St and steps) on a palygorshive vein surface in which at least two episodes of mineral deposition and faulting (St 1 and St 2) can be recognized. SOM: sense of movement. (e) Incipient development of foliation planes (S: solid lines) in a palygorskik vein (dotied line) suggesting the onset of ductile deformation; arrows indicate the sense of shear along the fault plane; the image has been rotaked clockwise from the original vertical position. 
fractured section of the Serrata de Nijar hills, a sector characterized by faulting at different scales, brecciation and development of large zones of fault gouge (Figure 2a,b). The samples were collected from both massive outcrops of fault gouge and discrete associated minor faults (Figure $2 \mathrm{~b}$ ). Given that rock crushing is intense in the former, the latter provided the best samples for field and laboratory structural and mineralogical studies. The mineralogical characterization of the samples was performed by X-ray diffraction (XRD), using a Siemens D-500 X-ray diffractometer with $\mathrm{CuK} \alpha$ radiation and a graphite monochromator. The samples used were random-powder specimens, which were scanned from 2 to $65^{\circ} 2 \theta$ at a scan speed of $0.02^{\circ} 2 \theta / 3 \mathrm{~s}$. Particle morphology and textural relationships were established by scanning electron microscopy (SEM) and transmission electron microscopy (TEM). The SEM observations were performed using a JEOL JSM 6400 microscope, operating at $20 \mathrm{kV}$ and equipped with a Link System energy dispersive X-ray microanalyser (EDX). Prior to SEM examination, freshly fractured surfaces of representative samples were air dried and coated with Au under vacuum. The TEM observations were performed by depositing a drop of diluted suspension on a microscopic grid with collodion. The chemical composition was obtained using analytical electron microscopy (AEM) with TEM on samples of great purity, using a JEOL 2000 FX microscope equipped with a double-tilt sample holder (up to a maximum of $\pm 45^{\circ}$ ) at an acceleration voltage of $200 \mathrm{kV}$, with $0.5 \mathrm{~mm}$ zeta-axis displacement and $0.31 \mathrm{~nm}$ pointto-point resolution. The microscope incorporates an OXFORD ISIS energy dispersive X-ray spectrometer (136 eV resolution at $5.39 \mathrm{keV}$ ) and has its own software for quantitative analysis. The structural formulae of palygorskite were calculated on the basis of $\mathrm{O}_{20}(\mathrm{OH})_{2}\left(\mathrm{OH}_{2}\right)_{2}$ per half unit-cell (e.g. Newman and Brown, 1987), whereas those of smectite were calculated on the basis of $\mathrm{O}_{20}(\mathrm{OH})_{4}$ oxygens per half unit-cell. All the $\mathrm{Fe}$ present was considered to be $\mathrm{Fe}^{3+}$, but the possible existence of $\mathrm{Fe}^{2+}$ was taken into account.

\section{GEOLOGY OF THE STUDY AREA}

The Almeria region (Figure la) is characterized by the presence of two of the most important Alpine complexes of southern Spain: Alpujarride and Nevado Filábrides (Figure 1b). These units were folded intensively during Late Oligocene-Early Miocene, and later underwent extensional collapse through major detachment systems in Middle-Late Miocene time (e.g. Doblas and Oyarzun, 1989; Platt and Vissers, 1989). The latter episode was accompanied by important calc-alkaline volcanism (andesites, dacites, rhyolites) and sedimentation within evaporitic sedimentary basins. Subsequent large $(+40 \mathrm{~km})$ ENE-WSW sinistral wrench faulting during the Miocene (Carboneras Fault Zone: CFZ)
(Huibregtse et al., 1998; Keller et al., 1997) gave rise to the formation of one of the most remarkable morphological features of the Nijar-San José sector, the so-called Serrata de Nijar (Figure 1b,c), a compressive duplex characterized by large-scale pervasive deformation of the Miocene sedimentary and volcanic units. Thus, the Serrata de Nijar can be regarded as an uplifted tectonic block formed within a transpression zone developed along the CFZ. From a structural viewpoint, the Serrata de Nijar duplex is characterized by a dominance of P-type shears over the more relatively common R-type (Keller et al., 1997) ( $\mathrm{P}$ and $\mathrm{R}$ nomenclature after Passchier and Trouw, 1998). The sedimentary units (limestone and gypsum beds) were folded intensively, whereas the volcanic rocks were either tectonically brecciated or transformed into massive zones of fault gouge (Figure $2 b$ ). The fault gouge consists of $\mathrm{cm}$ - to m-scale bands of a very fine clay-rich matrix with mm- to cm-scale clasts (Keller et al., 1997). The breccias vary considerably in type and size (Figure 2a-c). Some of the breccias record at least two episodes of brecciation, and we observe large (mscale) boulders of highly altered breccia within megabreccia (Figure 2b,c). Discrete color changes from red to green or white along the Serrata de Nijar mark zones in which ongoing fluid circulation induced precipitation of minerals such as goethite, chlorite and clays (Figure 2c). Although cataclasis dominates the tectonic deformation at the Serrata de Nijar, we have found evidence of localized brittle-ductile processes on clay minerals infilling secondary fault planes (Figure 2e).

\section{RESULTS}

The fine materials forming the fault gouge correspond to a well defined dioctahedral smectite, whereas palygorskite is only found in secondary faults associated with the main structure (Figure $2 \mathrm{~b}$ ). The fault gouge is composed of small (up to $1 \mathrm{~cm}$ in diameter), scattered, altered pebbles of andesitic rock embedded within a matrix of smectite, in which some original volcanic textural features of the sheared rock are still visible at the microscopic scale.

The combined SEM and XRD studies of these samples reveal the partial to total leaching of plagioclase and its replacement by smectite (Figures 3,4). The replacement textures include cavity infillings and feldspar replacements, together with later coatings developed on top of the earlier infillings and replacements (Figure 3). The TEM analyses of the Serrata de Nijar smectites show a mean $(n=8)$ structural formula of $\mathrm{Si}_{7.89} \mathrm{Al}_{0.11}\left(\mathrm{Al}_{2.64} \mathrm{Fe}_{0.23}^{3+} \mathrm{Mg}_{1.53}\right) \mathrm{O}_{20}(\mathrm{OH})_{4} \mathrm{Na}_{0.17}$ $\mathrm{K}_{0.02} \mathrm{Ca}_{0.13}$ (Table 1). This composition corresponds to a low-charged montmorillonite (mean value of 0.44 per half unit-cell), with $\mathrm{Ca}$ and $\mathrm{Na}$ as major exchangeable cations, and an average of 4.4 octahedral cations per half unit-cell. 
The Serrata de Nijar palygorskite shows an XRD pattern corresponding to both the monoclinic and orthorhombic forms of this mineral (Chisholm, 1990, 1992) (Figure 5). The samples are composed of very long fibers growing parallel along well defined undulating planes. These are in turn parallel to macroscopic features such as striations in the fault plane from which the sample was collected (Figure 2d). The use of kinematic indicators (congruous steps, striations; e.g. Doblas et al., 1997) allows recognition of at least two episodes of fault movement and palygorskite deposition along fault planes (Figure 2d), which agrees with the
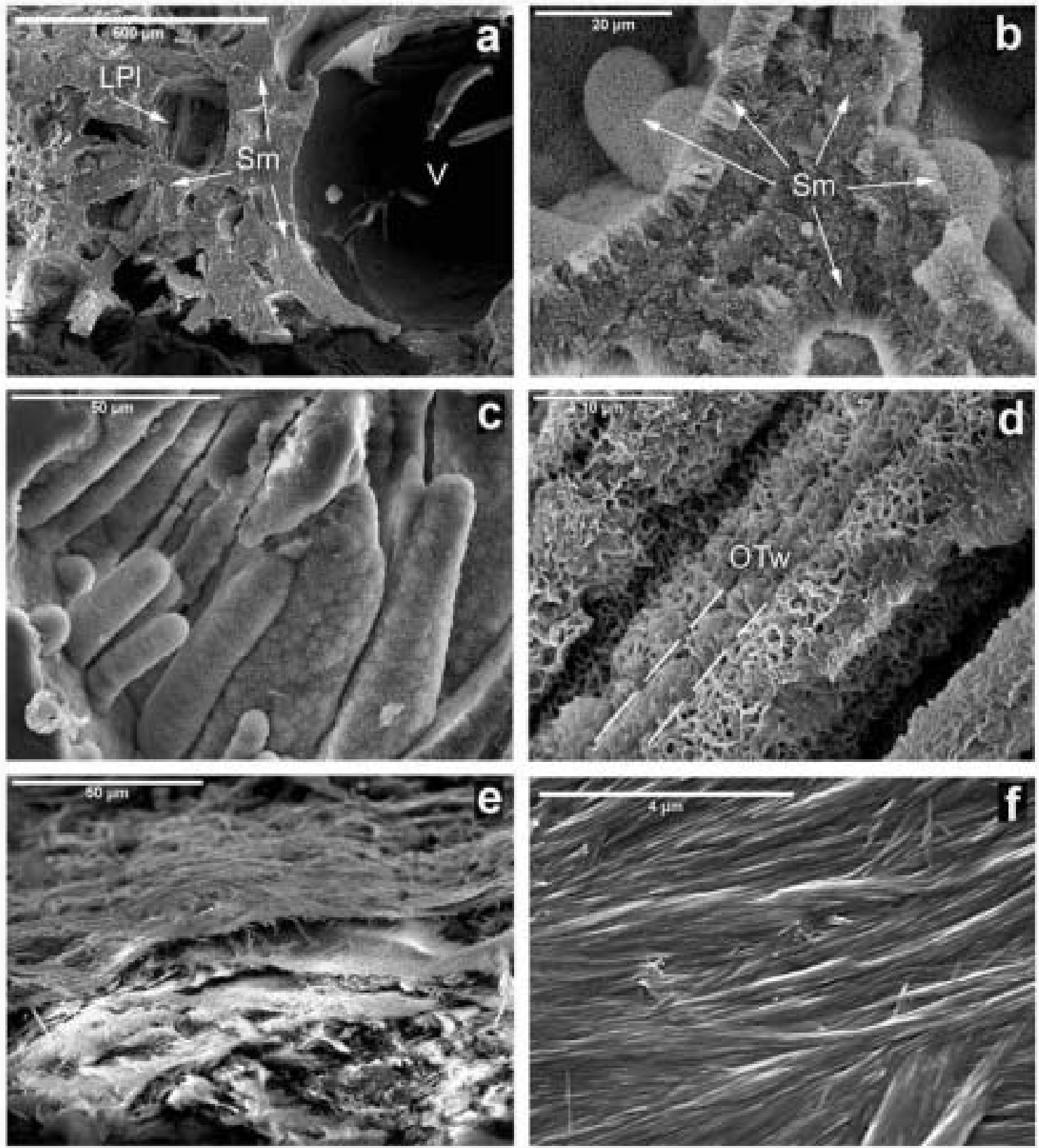

Figure 3. SEM images of smectike and palygorskik from the Serrata de Nijar. (a)Cavities corresponding to relict kextural features of the original andesitic volcanic rock, including leached plagioclase crystals (LPI) and vesicles (V). The rock has been entirely replaced bysmectite (Sm). (b) Partial cavityinfillings by smective (see arrows). (c) Detailedimage of cavitycoatings by smective. (d) Detailed image of an alkered plagioclase crystal that has been wotally replaced by smectike. Smectite probably grew in bands following the original twining (OTw; dashed lines) planes of the plagioclase crystal. (e) Layered vein of palygorskive fibers. (f) Detailed view of the palygorskite fibers. 
Table 1. Crystallochemical formulae of smectite (sample SND).

\begin{tabular}{lcccccccccc}
\hline & $\mathrm{Si}$ & ${ }^{\mathrm{IV}} \mathrm{Al}$ & $\Sigma \tau$ & ${ }^{\mathrm{VI}} \mathrm{Al}$ & $\mathrm{Fe}^{3+}$ & $\mathrm{Mg}$ & $\Sigma \mathrm{o}$ & $\mathrm{Ca}$ & $\mathrm{K}$ & $\mathrm{Na}$ \\
\hline SND1 & 7.86 & 0.14 & 8.00 & 2.55 & 0.29 & 1.59 & 4.43 & 0.13 & 0.03 & 0.18 \\
SND2 & 7.90 & 0.10 & 8.00 & 2.62 & 0.21 & 1.54 & 4.37 & 0.13 & 0.04 & 0.22 \\
SND3 & 7.86 & 0.14 & 8.00 & 2.68 & 0.20 & 1.52 & 4.40 & 0.12 & 0.01 & 0.18 \\
SND4 & 7.91 & 0.09 & 8.00 & 2.60 & 0.27 & 1.53 & 4.40 & 0.13 & 0.02 & 0.17 \\
SND5 & 7.89 & 0.11 & 8.00 & 2.62 & 0.25 & 1.52 & 4.39 & 0.13 & 0.01 & 0.18 \\
SND6 & 7.92 & 0.08 & 8.00 & 2.64 & 0.23 & 1.52 & 4.39 & 0.13 & 0.02 & 0.13 \\
SND7 & 7.90 & 0.10 & 8.00 & 2.71 & 0.19 & 1.52 & 4.42 & 0.10 & 0.02 & 0.13 \\
SND8 & 7.88 & 0.12 & 8.00 & 2.70 & 0.18 & 1.53 & 4.41 & 0.13 & 0.01 & 0.13 \\
Mean & 7.89 & 0.11 & 8.00 & 2.64 & 0.23 & 1.53 & 4.40 & 0.13 & 0.02 & 0.17 \\
& & & & & & & & & & \\
\hline
\end{tabular}

Number of cations on the basis of $\mathrm{O}_{20}(\mathrm{OH})_{4}$

polyphase character of deformation along the Serrata de Nijar block. The TEM analysis of dispersed samples of palygorskite shows the characteristic fibrous morphology and the following mean $(n=10)$ structural formula: $\mathrm{Si}_{7.95} \mathrm{Al}_{0.05} \mathrm{O}_{20}\left(\mathrm{Al}_{1.93} \mathrm{Fe}_{0.08} \mathrm{Mg}_{1.92}\right)(\mathrm{OH})_{2}\left(\mathrm{OH}_{2}\right)_{4} \mathrm{Na}_{0.09}$ $\mathrm{K}_{0.01} \mathrm{Ca}_{0.03} .4\left(\mathrm{H}_{2} \mathrm{O}\right.$ ) (Table 2), where $\mathrm{OH}_{2}$ represents bound water and $\mathrm{H}_{2} \mathrm{O}$ includes hygroscopic and zeolitic waters. This composition is very close to the ideal formula, with similar mean values of $\mathrm{Mg}$ and $\mathrm{Al}$. The samples have a minor proportion of tetrahedral substitutions, with a $\mathrm{Mg} / \mathrm{Al}$ ratio close to (0.97), and have a remarkable low $\mathrm{Fe}^{3+}$ octahedral content (0.08). The number of octahedral cations per half unit-cell is 3.93 on average. As a consequence of this composition, the exchangeable cations content is very small.

\section{DISCUSSION}

Palygorskite can form in marine or continental sedimentary environments, during pedogenesis of sedimentary and volcanic facies, and either as a direct precipitate from hydrothermal solutions, or as a replacement product during hydrothermal alteration processes. A major question regarding this work relates to the
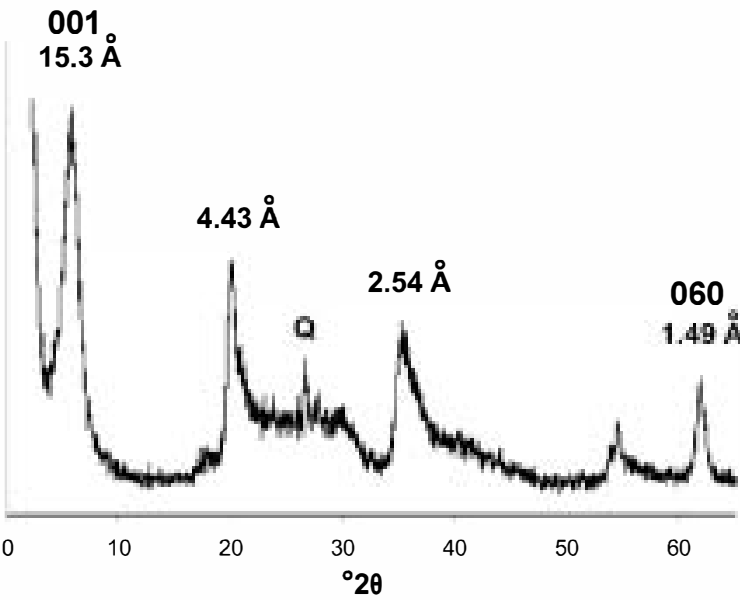

Figure 4. XRD pattern of pure dioctahedral smectite (sample SND) from the Serrata de Níjar. origin of the Serrata de Níjar palygorskite. In this respect, we must emphasize one major aspect of the problem: we are not dealing with altered surfaces of sedimentary or volcanic rocks but with palygorskite infilling faults. A second crucial aspect of the problem is the character of the studied samples: they are pure palygorskite fibers, i.e. no traces of precursor minerals are detected, either by SEM or XRD. In other words, the Serrata de Nijar palygorskite is not the alteration by-product of a former mineral present within the fault planes. Although this could be the consequence of total alteration of a former mineral, we must also take into account the fact that there is no mineralogical or textural transition from the palygorskite infillings to the hostrock, as is often the case in secondary veins (quartz, calcite, etc.) in metamorphic or hydrothermal scenarios. Thus, we are not dealing with alteration phenomena but with fault-cavity infilling. If the palygorskite fibers from Serrata de Nijar are not the by-product of rock-surface alteration, then we are left with one main possibility: the mineral must have been introduced from externally into the faults via fluids and subsequent deposition. There are

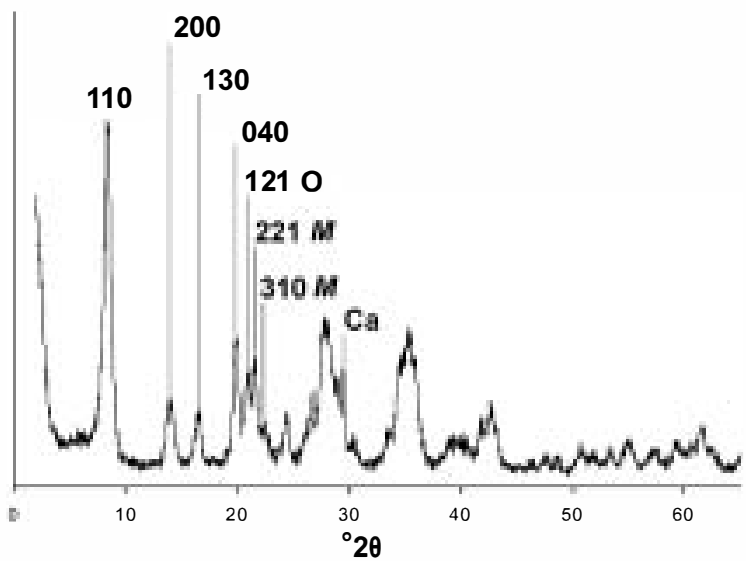

Figure 5. XRD pattern of well crystallized palygorskite (sample SNE) from the Serrata de Níjar. The diagram shows the reflections corresponding to the monoclinic $(M)$ and orthorhombic $(O)$ phases $(e . g$. Chisholm, 1990, 1992). Ca: minor peak of calcite. 
Table 2. Crystallochemical formulae of palygorskite (sample SNE).

\begin{tabular}{|c|c|c|c|c|c|c|c|c|c|c|c|}
\hline & $\mathbf{S i}$ & ${ }^{{ }^{\mathbf{I V}}} \mathbf{A l}$ & $\Sigma \tau$ & ${ }^{{ }^{\mathrm{VI}}} \mathbf{A l}$ & $\mathrm{Fe}^{3+}$ & Mg & $\mathrm{Ti}$ & $\Sigma_{0}$ & $\mathrm{Ca}$ & $\mathrm{K}$ & $\mathrm{Na}$ \\
\hline SNE1 & 8.00 & & 8.00 & 1.82 & 0.10 & 2.07 & 0.02 & 4.01 & & & \\
\hline SNE2 & 8.00 & & 8.00 & 2.02 & 0.12 & 1.80 & & 3.94 & 0.03 & 0.04 & 0.01 \\
\hline SNE3 & 7.89 & 0.11 & 8.00 & 1.95 & 0.07 & 1.93 & & 3.95 & 0.01 & 0.01 & 0.14 \\
\hline SNE4 & 8.00 & & 8.00 & 1.93 & 0.08 & 1.89 & & 3.90 & 0.15 & 0.02 & 0.02 \\
\hline SNE5 & 8.00 & & 8.00 & 1.84 & 0.10 & 1.86 & 0.01 & 3.81 & 0.01 & & 0.10 \\
\hline SNE6 & 7.95 & 0.05 & 8.00 & 1.96 & 0.07 & 1.92 & & 3.95 & & & 0.13 \\
\hline SNE7 & 7.85 & 0.15 & 8.00 & 1.91 & 0.06 & 2.03 & & 4.00 & 0.01 & & 0.14 \\
\hline SNE8 & 7.94 & 0.06 & 8.00 & 2.00 & 0.07 & 1.84 & & 3.91 & 0.01 & & 0.12 \\
\hline SNE9 & 8.04 & & 8.04 & 1.88 & 0.08 & 1.89 & 0.01 & 3.86 & 0.01 & 0.02 & 0.08 \\
\hline SNE10 & 7.88 & 0.12 & 8.00 & 1.95 & 0.07 & 1.94 & & 3.96 & 0.02 & & 0.13 \\
\hline Mean & 7.95 & 0.05 & 8.00 & 1.93 & 0.08 & 1.92 & 0.00 & 3.93 & 0.03 & 0.01 & 0.09 \\
\hline
\end{tabular}

Number of cations on the basis of $\mathrm{O}_{20}(\mathrm{OH})_{2}\left(\mathrm{OH}_{2}\right)_{2}$. Voids $<0.01$.

two possible means of achieving this: the fluids either moved downward (per descensum meteoric waters) or upward (hydrothermal solutions). The large size of the Serrata de Nijar palygorskite crystals may offer some clues regarding their origin. For example, sepiolite crystals formed under hydrothermal conditions are usually larger and have fewer defects than those generated in sedimentary environments (López Galindo and Sánchez Navas, 1989). Besides, volcanism (heat source) in the Almeria region lasted from the Langhian to the Tortonian, and caused widespread hydrothermal activity, leading to the formation of metallic ore deposits (e.g. gold epithermal deposits) and industrial minerals (bentonite, zeolite, alunite) (e.g. Linares, 1985; Reyes et al., 1987; Oyarzun et al., 1995) (Figure 1b). Moreover, some of the bentonite deposits formed precisely along the Serrata de Nijar structural block. On the other hand, volcanism and fault activity along the CFZ (Burdigalian onwards; Keller et al., 1997) coincided in time and space, and as shown by the altered character of the brecciated andesitic rocks (Figure 2c), we may assume that hydrothermal activity was important along the CFZ. Moreover, fault systems are preferential sites for fluid circulation, and as such, mineral deposition along faults during magmatic periods (anomalous geothermal gradients) is likely to be of hydrothermal origin.

Bowles et al. (1971) reported that deep-sea palygorskite (Atlantic Ocean) formed as primary precipitates by direct reaction between sea water and $\mathrm{Mg}$-rich hydrothermal solutions emanating from sea-floor fractures. Haji-Vassiliou and Puffer (1975) reported palygorskite and calcite in a hydrothermal vein that had its origin in a nearby mafic plutonic body. Furbish and Sando (1976) described palygorskite that formed by direct precipitation from hydrothermal solutions related to a pegmatite body intruding dunites. More recently Gibbs et al. (1993) reported hydrothermal palygorskite from the central California margin fracture zone. However, little has been said of the actual mechanisms of palygorskite formation within fault zones subjected to hydrothermal circulation. Mineral formation in this environment requires a source of cations (a rock with $\mathrm{Mg}$ silicates), a mechanism that can account for the release of these cations (e.g. hydrolysis), a channel for the movement of the hydrothermal fluids (e.g. a fault or fault zone), and flnally, a precipitation mechanism. In our case, the source rock is provided by the intensively faulted and brecciated andesitic rocks that crop out along the Serrata de Nijar block. Pyroxene is one of the main mineral phases of these rocks, and a potential source of $\mathbf{M g}^{2+}$ cations. In the case of pyroxenes, the cations from $M 2$ sites (e.g. $\mathrm{Ca}$ in diopside) are preferentially released during hydrolysis, although eventually all species, including the $M 1$ cations (e.g. $\mathrm{Mg}$ in diopside), are released from the mineral (Murphy and Helgeson, 1987). Given that the dissolution mechanism for wollastonite is very similar to that of pyroxenes (Murphy and Helgeson, 1987), we can simplify the case in the following way:

$$
\mathrm{MgSiO}_{3}+2 \mathrm{H}^{+} \rightarrow \mathrm{H}_{2} \mathrm{SiO}_{3}+\mathrm{Mg}^{2+}
$$

Thus the hydrolysis of $\mathbf{M g}$ pyroxene would result in the release of $\mathrm{Mg}^{2+}$ cations, a key prerequisite for palygorskite formation. As hydrolysis proceeds, $\mathrm{H}^{+}$ions are consumed, and eventually neutral or even alkaline conditions can be reached. It is well known that alkaline conditions favor tetrahedral coordination for $\mathrm{Al}^{3+}$, though the presence of $\mathrm{Mg}^{2+}$ in the system modifies this tendency, resulting in octahedral coordination for $\mathrm{Al}^{3+}$, a key prerequisite for inducing clay mineral formation.

On the other hand, faults in tectonically active regions provide the ideal conduits for transport and deposition of mineral phases, very much like the processes that lead to ore deposition within dilation zones subjected to sudden decompression (Sibson, 1990). We must bear in mind that faults are subjected to episodic activity controlled by brittle failure during seismic activity. It is precisely during these events that fluids move along the fault planes, as shown by the seismic pump mechanism of Sibson (1990). The fluids are pumped up during cavity openings along faults, marking the passage from lithostatic to hydrostatic conditions. The process results in sudden drops in 


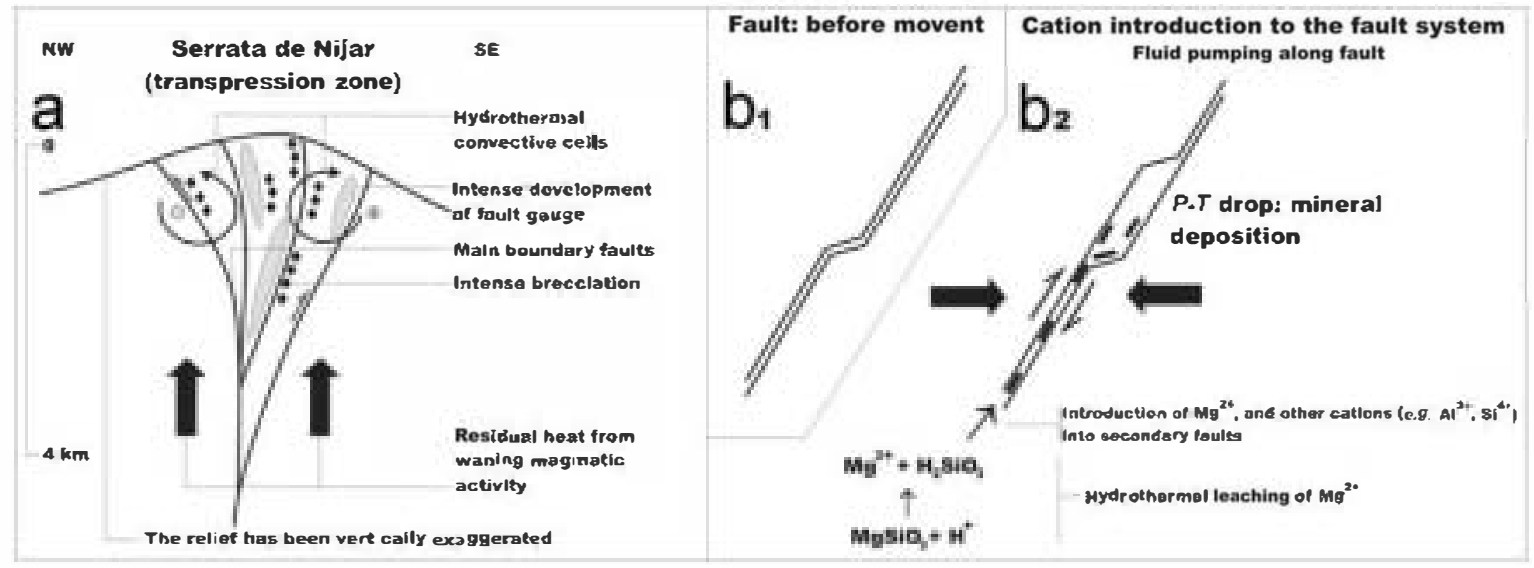

Figure 6. Schematic geological model for palygorskive formation in the Serrata de Nijar deformation zone. Representation of the Serrata de Nijar internal structure corresponds to that expected in a compressional duplex (e.g. Davis and Reynolds, 1996). (a) Main structural units within the fault zone including breccia and fault gouge zones, suggested hydrothermal system, and probable pathways for fluid circulation. (b) Fault behaviorprior to (b1) andduring rock failure (b2) (e.g. Sibson, 1987). The fluids are pumped up during cavityopening. This marks the passage from lithostatic (in b1) to hydrostatic conditions (in b2) leading to a sudden drop in pressure (e.g. Sibson, 1990), which may favor mineral deposition. The suggested model involves ongoing hydrothermalleaching of $\mathrm{MB}^{2+}$ and other cations from the volcanic rocls, and the introduction with the fluids into the recently opened cavity (b2), where mineral deposition would take place.

pressure, which may lead to chemical disequilibrium and mineral deposition. Evidence supporting the episodic brittle failure in the studied faults is provided by the analysis of kinematic indicators in the palygorskite veins, which indicate at least two episodes of faulting (Figure 2d). Additional evidence is provided by the relatively small degree of deformation presented by the palygorskite fibers. For example, Vrolik and van der Pluijm (1999) reported folding in the clay gouges of faults: if the minerals are synkinematic, then it follows that they must be strongly affected by the deformation process. On the contrary, if the minerals form along dilational cavities, deformation can be kept to a minimum as in the present case. In fact, we only observe an incipient development of foliation planes along the palygorskite vein, which indicates that some flattening also occurred within the fault plane (Figure 2e).

Although we cannot fully quantify our suggested hydrothermal process for the Serrata de Nijar case, we may nevertheless constrain the geological conditions of the system (Figure 6). As shown by the stability conditions for palygorskite (Imai and Otsuka, 1984), this mineral is stable below a temperature range of 220-275 $\mathrm{C}(P=24.5 \mathrm{MPa})$. Above these temperatures, palygorskite transforms into trioctahedral smectite. These $P-T$ conditions are easily met within the uppermost $\sim 3 \mathrm{~km}$ of shear zones (hydrostatic pressure), where incohesive gouge and breccia account for most of the fault rocks (Sibson, 1990) (Figure 6).

\section{CONCLUSIONS}

The Serrata de Nijara is a highly fractured realm comprising fault rocks (tectonic breccias and fault gouge) which, as shown by field and laboratory studies, underwent hydrothermal alteration. Wc suggest that a combination of active magmatism and faulting may have led to widespread fluid circulation along fault planes and fault zones, hydrothermally altering the tectonically disrupted volcanic rock units (andesites). Wc further suggest that Mg-rich fluids originating from the hydrothermal alteration of the volcanic rocks may have played a crucial role in the deposition of palygorskite along fault planes, during brittle rock failure and cavity openings. This process would be marked by the passage from lithostatic to hydrostatic conditions and a sudden drop in pressure, thus favoring mineral deposition within the opened cavities. As shown by the structural analysis of fault infillings, both deformation and fluid circulation were episodic processes.

\section{ACKNOWLEDGMENTS}

We thank the Faculty of Geological Sciences (UCM) and the Junta de Castilla y León (Grant SA017A05). Additional funding was obtained from Grant 910386 (Universidad Complutense, Grupos de Investigación). The work benefited from comments by Derek Bain, Javier Cuadros and Ray Ferrell.

\section{REFERENCES}

Bowles, F., Angino, A., Hoskerman, W. and Galle, K. (1971) Precipitation of deep-sea palygorshive and sepiolite. Earth and Planetary Science Letters, 11, 324-332.

Chisholm, J.E. (1990) An X-ray powder diffraction study of palygorskik. The Canadian Mineralogist, 28, 329-339.

Chisholm, J.E. (1992) Powder-diffraction patierns and struotural models for palygorskiv. The Canadian Mineralogist, 30, 61-73.

Davis, G.H. and Reynolds, S.J. (1996) Structwod Geology of Rocks and Regions. John Wiley and Sons, New York, 776 pp. 
Doblas, M. and Oyarzun, R. (1989) Neogene extensional collapse in the western Mediterranean (Betic-Rif Alpine orogenic belt): implications for the genesis of the Gibraltar Arc and magmatic activity. Geology, 17, 430-433.

Doblas, M., Mahecha, V., Hoyos, M. and López Ruiz, J. (1997) Slickenside and fault surface kinematic indicators on active normal faults of the Alpine Betic cordilleras, Granada, southern Spain. Journal of Structural Geology, 19, 159-170.

Eaton, P.C. and Setterfield, T.N. (1993) The relationship between epithermal and porphyry hydrothermal systems within the Tavua Caldera, Fiji. Economic Geology, 88, 1053-1083.

Furbish, W.J. and Sando, T.W. (1976) Palygorskite by direct precipitation from a hydrothermal solution. Clay Minerals, 11, 147-151.

Gibbs, A.E., Hein, J.R., Lewis, S.D. and McCulloch, D.S. (1993) Hydrothermal palygorskite and ferromanganese mineralization at a central California margin fracture zone. Marine Geology, 11, 47-65.

Haji-Vassiliou, A. and Puffer, J.H. (1975) A macrocrystalline attapulgite-palygorskite occurrence in calcite veins. American Mineralogist, 60, 328-330.

Heald, P., Foley, N.K. and Hayba, D.O. (1987) Comparative anatomy of volcanic-hosted epithermal deposits: acidsulfate and adularia-sericite types. Economic Geology, 82, 26.

Hemley, J.J. and Jones, W.R. (1964) Chemical aspects of hydrothermal alteration with emphasis on hydrogen metasomatism. Economic Geology, 59, 538-567.

Hemley, J.J., Hostetler, P.B., Gude A.J. and Mountjoy, W.T. (1969) Some stability relations of alunite. Economic Geology, 64, 599-612.

Huibregtse, P. Alebeek, H.V., Mattijs, Z. and Biermann, C. (1998) Palaeostress analysis of the northem Nijar and southern Vera basins: constraints for the Neogene displacement history of major strike-slip faults in the Betic Cordilleras, SE Spain. Tectonophysics, 300, 79-101.

Imai, N. and Otsuka, R. (1984) Sepiolite and palygorskite in Japan. Pp. 211-232 in: Palygorskite-Sepiolite: Occurrence, Genesis and Uses (A. Singer and E. Galán, editors). Developments in Sedimentology, 37, Elsevier, Amsterdam.

Keller, J.V.A., Hall, S.H. and McClay, K.R. (1997) Shear fracture pattern and microstructural evolution in transpressional fault zones from field and laboratory studies. Jour nal of Structural Geology, 19, 1173-1187.
Linares, J. (1985) The processes of bentonite formation in Cabo de Gata, Almería, Spain. Mineralogica et Petrographica Acta, 29A, 17-33.

López Galindo, A. and Sánchez Navas, A. (1989) Criterios morfológicos, cristalográficos y geoquímicos de diferenciación entre sepiolitas de origen sedimetario e hidrotermal. Boletín de la Sociedad Española de Mineralogia, 12, 375-384.

Montoya, J.W. and Hemley, J.J. (1975) Activity relations and stabilities in alkali feldspar and mica alteration reactions. Economic Geology, 70, 577-583.

Murphy, W.M. and Helgeson, H.C. (1987) Thermodynamic and kinetic contraints on reaction rates among minerals and aqueous solutions. III. Activated complexes and the pHdependence of the rates of feldspar, pyroxene, wollastonite, and olivine hydrolysis. Geochimica et Cosmochimica Acta, 51, 3137-3153.

Newman, A.C.D. and Brown, G. (1987) The chemical constitution of clays. Pp. 1-128 in: Chemistry of Clays and Clay Minerals (A.C.D. Newman, editor). Monograph 6, Mineralogical Society, London.

Oyarzun, R., Marquez, A., Ortega, L., Lunar, R. and Oyarzún, J. (1995) A late Miocene metallogenic province in southeast Spain: atypical Andean-type processes on a smaller scale. Transactions of the Institution of Mining and Metallurgy, 104, 197-202.

Passchier, C.W. and Trouw, R.A.J. (1998) Microtectonics. Springer, Berlin, 289 pp.

Platt, J.P. and Vissers, R.L.M. (1989) Extensional collapse of thickened continental lithosphere: a working hypothesis for the Alboran Sea and Gibraltar Arc. Geology, 17, 540-543.

Reyes, E., Caballero, E., Huertas, F. and Linares, J. (1987) Bentonite deposits from the Cabo de Gata region, Almería, SE Spain. The Sixth Meeting of the European Clay Groups, Seville, Spain; Guide Book for Excursions, pp. 7-31.

Sibson, R.H. (1987) Earthquake rupturing as a hydrothermal mineralizing agent. Geology, 15, 701-704.

Sibson, R.H. (1990) Faulting and fluid flow. Pp. 93-132 in: Fluids in Tectonically Active Regimes of the Continental Crust (B.E. Nesbitt, editor). Short Course, Mineralogical Association of Canada, Vancouver.

Vrolik, P. and van der Puijm, B.A. (1999) Clay gouge. Journal of Structural Geology, 21, 1039-1048. 